\title{
Combination of Zeolite, Charcoal and Water Spinach as Integrated Filters to Reduce Ammonia Level in Aquaponic System
}

\author{
Fista Yohana Tanaya ${ }^{1}$, Kisworo ${ }^{1 *}$, and Guruh Prihatmo ${ }^{1}$ \\ ${ }^{1}$ Faculty of Biotechnology, Universitas Kristen Duta Wacana, Yogyakarta, Indonesia
}

\begin{abstract}
Aquaponic is a combination of aquaculture and hydroponic plants in the recirculation system. The aquaponic system has a constraint in the form of ammonia which is produced by fish metabolism. In order to increase the productivity of fish and plants in aquaponics, an approach by integrating filters and biofilter could be used to reduce ammonia waste. The aim of this research was to study the use of zeolite, charcoal, and water spinach as components of integrated filters to reduce ammonia concentration in an aquaponic system. This research was conducted for four weeks with three repetitions of water sampling sourced from pond, filters, and output. The results of this study indicated that the use of combination of zeolite, charcoal and water spinach as componentof integrated filters can reduce ammonia throughout the research period.
\end{abstract}

Keywords: aquaponic, ammonia reduction, integrated filters

\section{Introduction}

As global population continues to grow, the demand for vegetable and meat as food components will also be increased. These phenomenon requires solution for an effective and efficient cultivation system that produce more than one farming product from one effort. A system that is able to answer those challenges is aquaponic. An aquaponic is defined as combination of aquaculture and hydroponic plant cultivation in a recirculation system (Nugroho et al., 2012). In this system, metabolic waste and feed residue from aquaculture are used as nutrients for plant growth (Graber and Junge, 2009; Wahyuningsih et al., 2015).

Fish, as a constituent of aquaculture, produces nitrogen waste from their metabolism which contain $80-90 \%$ of ammonia and $10 \%$ of urea (Norjanna et al., 2015). Ammonia content in water itself consists of ammonia $\left(\mathrm{NH}_{3}\right)$ and ionized

\footnotetext{
* Corresponding Author:

Kisworo

Faculty of Biotechnology, Universitas Kristen Duta Wacana, Jl. Wahidin Sudirohusodo 5-25, Yogyakarta, Indonesia, 55224

E-mail: kisworo@yahoo.com
}

ammonia or ammonium $\left(\mathrm{NH}^{4+}\right)$. These two types of ammonia are called Total Ammonia Nitrogen (TAN) (Wahyuningsih et al., 2015). Plants can absorb ammonium $\left(\mathrm{NH}^{4+}\right)$ and nitrate $\left(\mathrm{NO}^{3-}\right)$ from fish metabolism as a source of nutrition with the help of nitrifying bacteria (Graber and Junge, 2009; Lund, 2014; Norjanna, et al., 2015). Despite of its useful value, ammonia content can also have a negative impact on aquaponic systems. High levels of ammonia can cause death to farmed fish and cultivated plants. If released to ecosystem, ammonia can cause eutrophication and other environmental problems (Hastuti and Subandiyono, 2011; $\mathrm{Hu}$ et al., 2015). Refering to the potential problem that ammonia can bring, specific treatment to reduce ammonia level in an aquaponic system is needed.

The use of recirculation system without addition of plants is able to reduce 31-43\% of ammonia concentrations (Djokosetiyanto, et al., 2006; Putra and Pamukas, 2011). Plants that are grown in aquaponic system could reduce $58 \%$ of Total Ammonia Nitrogen (TAN) (Setijaningsih, 2009), but this ability leads to plant growth decrease (Effendi, 2003). Accumulation of ammonia will further occured because the presence of plants as biofilter is not $100 \%$ effective. Therefore, it is necessary to add another component to reduce ammonia level. 
Zeolite and activated charcoal could be used as additional filters in an aquaponic system because of their ability to purify water and neutralize toxic ammonia compounds (Widayat, et al., 2010). It is expected that the addition of a filter in the aquaponics system can reduce and maintain ammonia level below $0.8 \mathrm{ppm}$ as standard threshold (Anonim, 2005). The aim of this research was to study the application integrated filters that consist of zeolite, charcoal and water spinach to reduce ammonia level in aquaponic systems. Zeolite and charcoal were used as representation of common water filters, while water spinach represented biofilter.

\section{Materials and Methods \\ Location and Time of Research}

The research was conducted in Kratonan, Serengan, Surakarta, from January to April 2020. Water sampling for analysis of water quality (temperature, TDS, $\mathrm{pH}$ and DO), fish and plant growth measurements were carried out in situ. Total ammonia content was analyzed in labolatories of Balai Besar Teknik Kesehatan Lingkungan dan Pencegahan Penyakit (BBTKLPP) Yogyakarta.

\section{Materials}

Main equipment used in this experiment is fish pond (Figure 1) that is constructed from several materials such as tarp, water pumps, aerator, PVC pipes, PVC pipe connectors, drum, rockwools, net pots, fresh water and inoculum of nitrifying bacteria. Catfish (Clarias gariepinus) was employed as fish component in this aquaponic. Each of 500 individual catfish has initial body length of $17-18 \mathrm{~cm}$. Catfish were feeded with Hi-Pro-Vite 781-2. Plant component that was used in this system was water spinach (Ipomoea aquatica Forsk). Water spinach also served as biofilter in aquaponic system. Materials for filters in this system consist of zeolite and charcoal. For measuring plant and fish growth, some materials like stationery, balance, ruler, tray were needed. For measuring environmental parameters, several materials were used such as dark bottles, erlenmeyers, beker glass, thermometer, TDS meter, $\mathrm{pH}$ meter and $\mathrm{DO}$ kit.

\section{Measurement of Water Quality}

Water samples that were used for analysis of Dissolved Oxygen (DO), Biochemical Oxygen Demand (BOD), Total Dissolved Solid (TDS), temperature, $\mathrm{pH}$, and ammonia were collected 4 times during 4 weeks of experiments with 3 replications from 3 sampling points namely fish pond (input), filter tank, and output.

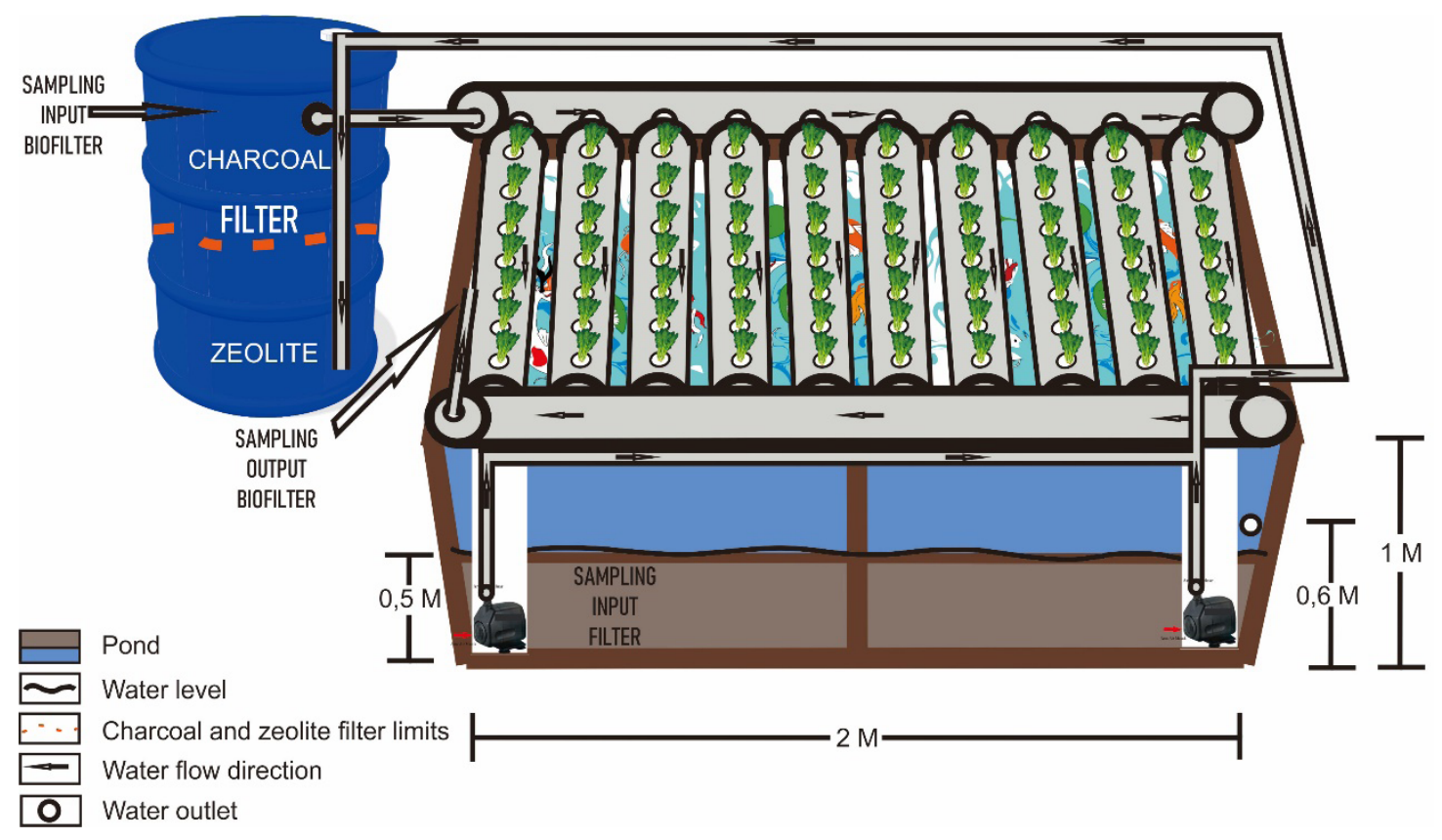

Figure 1. Fish pond design 


\section{Measurement of Fish and Plant Growth}

\section{a. Fish Growth}

Parameters of fish growth consist of absolute weight growth, absolute length growth, feed conversion ratio (FCR), and survival rate. Each measurement was carried out at the beginning of each week. Random 100 individual fish were used as measured samples.

- Absolute weight growth

The calculation of absolute weight growth used the Weatherley formula (Dewantoro, 2001) as follows:

$$
\mathrm{W}=\mathrm{W}_{\mathrm{t}}-\mathrm{W}_{0}
$$

where,

$\mathrm{W}=$ Absolute weight growth $(\mathrm{g})$

$W_{t}=$ Weight of fish at the end of fish farming (g)

$\mathrm{W}_{0}=$ Weight of fish at the beginning of fish farming $(\mathrm{g})$

- Absolute Length Growth

Absolute length growth was calculated using the formula described by Effendi et al., 2006 as follows:

where,

$$
\mathrm{L}=\mathrm{L}_{2}-\mathrm{L}_{1}
$$

$\mathrm{L}=$ Absolute length growth $(\mathrm{cm})$

$\mathrm{L}_{2}=$ Length fish at the end of fish farming (cm)

$\mathrm{L}_{1}=$ Length fish at the befinning of fish farming $(\mathrm{cm})$

- Feed Conversion Ratio (FCR)

The FCR was calculated using formula described by Yuwono et al. (2005) as follows:

$$
\mathrm{FCR}=\mathrm{F} /\left(\mathrm{W}_{\mathrm{t}}+\mathrm{D}+\mathrm{W}_{\mathrm{o}}\right)
$$

where,

$\mathrm{FCR}=$ Feed Conversion Ratio $(\mathrm{kg})$

$\mathrm{F}=$ Feed consumption $(\mathrm{g})$

$\mathrm{Wt}=$ Weight of fish at the end of fish farming (g)

$\mathrm{W}_{\mathrm{o}}=$ Weight of fish at the beginning of fish farming $(\mathrm{g})$

$\mathrm{D}=$ Weight of dead fish $(\mathrm{g})$
- Survival rate

The survival rate (SR) was calculated using the formula according to Effendi (1979), as follows:

$$
\mathrm{SR}=N_{t} / N_{0} \times 100 \%
$$

where,

$\mathrm{SR}=$ Survival of seeds $(\%)$

$N_{t}=$ Number of fish at the end of fish farming

$\mathrm{N}_{0}=$ Number of fish at the beginning of fish farming

\section{b. Plant Growth}

Plant growth was measured on the comparison of plant weight, length, and number of leaves at the beginning and end of cultivation. Measurement of these parameters were conducted once per week.

\section{Result \\ Water Quality}

Observation of water quality was carried out for 4 consecutive weeks, each on the same day and hour. Measurement of DO, BOD, TDS, temperature, $\mathrm{pH}$ showed fluctuative values (Table 1). Temperature value and $\mathrm{pH}$ scale of pond water were observed still on normal range for aquaponics system. Measurement on DO concentration showed that only result from third week was considered within normal range. BOD values measured from pond water during experiment were considered within normal range (1-2 ppm). Fluctuation on TDS level were observed during experiment with a tendency of its increasing level at the end of experiments period.

\section{Ammonia Level in Aquaponics Systems}

Based on the observations made on ammonia levels in water from ponds, filters, and biofilters for 4 consecutive weeks, it was found that ammonia levels tended to be fluctuated each week (Table 2). The best ammonia level was measured at week 2 from all water samples from pond, filter and output. Amonnia level of water for aquaponic should be less than 0.8 ppm (Anonim, 2005). 
Table 1.Water quality observations in the aquaponics system

\begin{tabular}{|c|c|c|c|c|c|c|c|c|c|c|}
\hline & \multicolumn{5}{|c|}{ Week 1} & \multicolumn{5}{|c|}{ Week 2} \\
\hline & $\begin{array}{c}\mathrm{DO} \\
(\mathrm{ppm})\end{array}$ & $\begin{array}{l}\text { TDS } \\
(\mathrm{ppm})\end{array}$ & $\begin{array}{c}\text { Temperature } \\
\left({ }^{\circ} \mathrm{C}\right)\end{array}$ & $\mathrm{pH}$ & BOD & $\begin{array}{c}\mathrm{DO} \\
(\mathrm{ppm})\end{array}$ & $\begin{array}{c}\text { TDS } \\
\text { (ppm) }\end{array}$ & $\begin{array}{c}\text { Temperature } \\
\left({ }^{\circ} \mathrm{C}\right)\end{array}$ & $\mathrm{pH}$ & BOD \\
\hline Pond & 2.12 & 1170.00 & 28.60 & 7.07 & 1.12 & 1.12 & 765.00 & 27.30 & 7.07 & 1.05 \\
\hline Filter & 1.80 & 1160.00 & 29.20 & 7.10 & 0.84 & 0.84 & 773.00 & 27.70 & 7.20 & 1.25 \\
\hline \multirow[t]{3}{*}{ Output } & 2.67 & 1160.00 & 28.80 & 7.40 & 1.27 & 1.27 & 754.00 & 27.80 & 7.07 & 1.29 \\
\hline & \multicolumn{5}{|c|}{ Week 3} & \multicolumn{5}{|c|}{ Week 4} \\
\hline & $\begin{array}{c}\mathrm{DO} \\
(\mathrm{ppm})\end{array}$ & $\begin{array}{l}\text { TDS } \\
(\mathrm{ppm})\end{array}$ & $\begin{array}{c}\text { Temperature } \\
\left({ }^{\circ} \mathrm{C}\right)\end{array}$ & $\mathrm{pH}$ & BOD & $\begin{array}{c}\mathrm{DO} \\
(\mathrm{ppm})\end{array}$ & $\begin{array}{l}\text { TDS } \\
\text { (ppm) }\end{array}$ & $\begin{array}{c}\text { Temperature } \\
\left({ }^{\circ} \mathrm{C}\right)\end{array}$ & $\mathrm{pH}$ & BOD \\
\hline Pond & 3.20 & 1236.67 & 27.27 & 8.00 & 2.56 & 1.81 & 2410.00 & 29.90 & 7.47 & 0.47 \\
\hline Filter & 2.64 & 1353.33 & 27.17 & 8.20 & 0.79 & 2.27 & 2210.00 & 30.10 & 7.10 & 1.43 \\
\hline Output & 3.15 & 1353.33 & 27.60 & 7.90 & 1.81 & 1.11 & 2490.00 & 29.10 & 7.13 & 0.47 \\
\hline
\end{tabular}

Table 2. Ammonia levels in the aquaponics system

\begin{tabular}{lcrrr}
\hline & Week 1 & Week 2 & Week 3 & Week 4 \\
\cline { 2 - 5 } & $\begin{array}{c}\text { Ammonia } \\
(\mathrm{ppm})\end{array}$ & $\begin{array}{c}\text { Ammonia } \\
(\mathrm{ppm})\end{array}$ & $\begin{array}{c}\text { Ammonia } \\
(\mathrm{ppm})\end{array}$ & $\begin{array}{c}\text { Ammonia } \\
(\mathrm{ppm})\end{array}$ \\
\hline Pond & 0.52 & 0.47 & 3.45 & 4.95 \\
Filter & 0.57 & 0.65 & 5.71 & 1.35 \\
Output & 1.23 & 0.46 & 2.88 & 1.97 \\
\hline
\end{tabular}

\section{Growth of Catfish}

Observations on the growth of catfish showed that the number of dead fish was increasing over time. Measurement of each growth parameter showed the best result was only observed on week 2 , while the worst one occurred at week 3 (Table 3 ).

\section{Growth of Water Spinach}

Growth of water spinach was fluctuative during observation (Table 4). Plant length and number of leaves showed maximum results at week 3 and week 4 , while the best result for plant weight was obtained on week 1 to week 2 . The best conditions for water spinach morphology was observed on week 2 by appearance of bright green stems and leaves (Figure 2). However, plant morfologhy turned onto bad shape on week 4 . It was showed by the breaking down of stem and color change of leaves from bright green onto pale green or yellowish green (Figure 3).

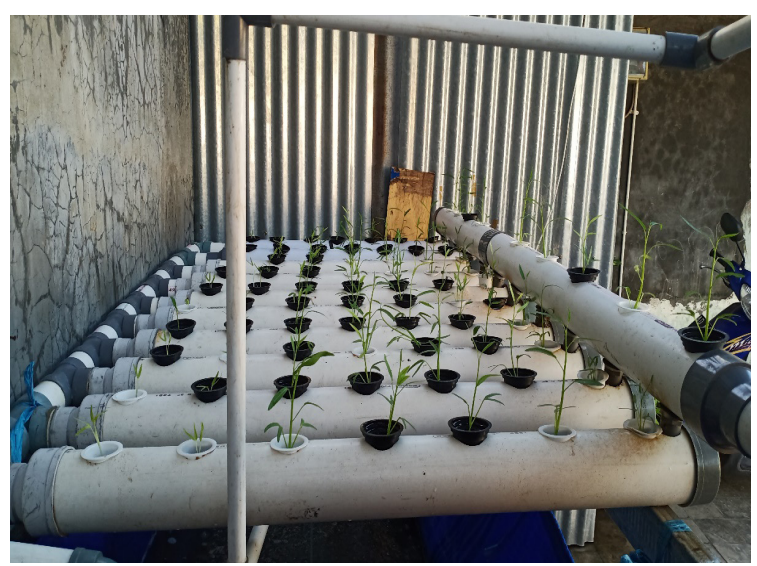

Figure 2. Condition of water spinach at week 2

\section{Discussion \\ Water Quality}

Water temperature did not directly affect metabolism of plants in the aquponics system because air temperature also has its influence on water temperature (Telaumbanua et al., 2016). In this study, water temperature

Table 3. Growth of catfish (Clarias gariepinus) in the aquaponic system

\begin{tabular}{lcccc}
\hline & Week 1 & Week 2 & Week 3 & Week 4 \\
\cline { 2 - 5 } & $23 / 02 / 2020$ & $01 / 03 / 2020$ & $08 / 03 / 2020$ & $15 / 03 / 2020$ \\
\hline Number of Dead Fish & 5 & 6 & 12 & 18 \\
Number of Survived Fish & 495 & 489 & 482 & 472 \\
Total Feed (kg) & 46.2 & 51.8 & 57.4 & 63 \\
Average Length (cm) & 22.50 & 23.76 & 24.01 & 25.14 \\
Average Weight (g) & 90.41 & 103.88 & 107.15 & 120.54 \\
Feed Convertion Rate (FCR) & 1.022 & 1.007 & 1.095 & 1.096 \\
Survival Rate (SR) & 0.99 & 0.98 & 0.95 & 0.92 \\
\hline
\end{tabular}


Table 4. Observations of the growth of water spinach (Ipomoea aquatica Forsk.)

\begin{tabular}{lcccc}
\hline & Week 1 & Week 2 & Week 3 & Week 4 \\
\cline { 2 - 5 } & $23 / 02 / 2020$ & $01 / 03 / 2020$ & $08 / 03 / 2020$ & $15 / 03 / 2020$ \\
\hline Average Length $\mathbf{( c m )}$ & 7.29 & 17.59 & 25.45 & 40.36 \\
Average Number of Leaves & 5.64 & 9.36 & 11.18 & 15.27 \\
Average Weight $\mathbf{( g )}$ & 7.82 & 10.09 & 11.91 & 12.18 \\
\hline
\end{tabular}

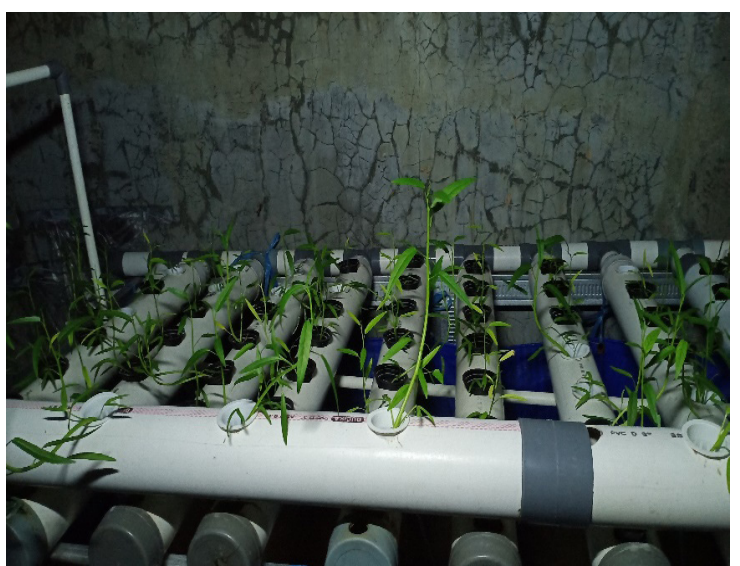

Figure 3. Condition of water spinach at week 4

ranged from $27.17^{\circ} \mathrm{C}-30.10^{\circ} \mathrm{C}$ (Table 1$)$. This range is categorized as safe or normal for the growth and survival of catfish (Nisrinah, 2013), and safe for bacteria motility and reproduction (Salle, 1961).

Exponent of hydrogen $(\mathrm{pH})$ scale that was measured on this research showed a range between 7.07 to 8.20 (Table 1). Catfish can tolerate and live in wide range of water $\mathrm{pH}$, from acidic ( $\mathrm{pH}$ scale 6.4) to alkaline ( $\mathrm{pH}$ scale 9$)$ as mentioned by Boyd and Nill (1982) and Augusta (2016). Nitrification produces acidic condition that affects bacterial metabolism. When ammonia compounds are broken down into ammonium, it will provide source of nutrition for bacteria. TDS concentration does not describe water quality specifically and it is considered as one of many indicators to determine water quality (Atima, 2015). TDS concentration depend on the number of ions or compounds such as ammonia, nitrite and nitrate (Machdar, 2018). It is suggested that the decrease of TDS concentration that occurred on week 1 to week 2 (Table 1 ) was due to the oxidation and nitrification process of bacteria that worked optimally to convert ammonia produced by catfish. In addition, water spinach which are in a period of rapid growth have an important role in absorbing nitrate (Effendi et al., 2016). The increase of TDS concentration that was occured in weeks 2 to 4 was caused by increase of fish metabolic waste. The overwhelming fish metabolic waste in the form of ammonia could not be handled by plants, filters, and bacteria for its reduction.

Dissolved Oxygen (DO) concentration that was observed in this research showed fluctuating results, where all DO values in pond water (Table 1 ) were below standard threshold value of 3 ppm (Augusta, 2016). This low DO concentration resulted in a higher level of ammonia that might lead to toxicity in the pond water, and causes shifting of equilibrium reaction and inhibits the oxidation process (Widyastuti, 2008; Wahyuningsih, et al., 2015).

\section{Ammonia Reduction in Aquaponics Systems}

Reduction of ammonia level was observed on water that was used in this aquaponic system. Steps of ammonia reduction in this study began from the pond water as a source of ammonia to the filter (zeolite and charcoal), then passed through water spinach as biofilter which will then be flowed back to the pond. Ammonia produced by catfish in this system will be reduced by filtering process, nitrification by bacteria, and nitrate absorption by plants as biofilter.

Reduction of ammonia concentration or level that is shown in Figure 4 was created based on ammonium level data on Table 2. The reduction rate of ammonia was calculated from the substraction of ammonia level of output water (as the end step of circulation) to ammonium level of pond water as the source of ammonium due to its function as fish farming media. 


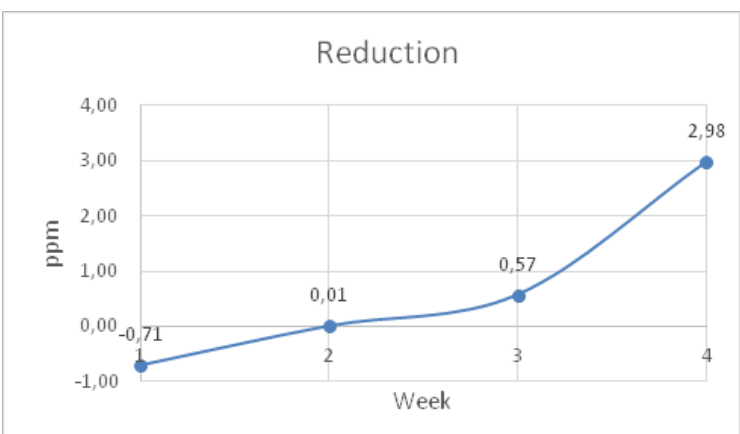

Figure 4. Reduction rate of ammonia level

Based on Figure 4, it can be seen that the highest reduction rate occurs on week 4 , followed by week 3 , week 2 , and week week 1. Amonnium reduction on week 1 was not obviously observed because the circulation system was not optimally worked. The level of ammonia reduction on week 1 was $-0.71 \mathrm{ppm}$. This value might be caused by the presence of cavities between zeolites and charcoal and led to the unfiltered metabolic waste flow in the output pipe and increased ammonia level on output water (Table 1). The value of ammonia reduction at week 2 was $0.01 \mathrm{ppm}$. This showed that the reduction of ammonia in the aquaponics system was starting to be well functioned. The reduction process occured in the third week was increased from the previous week because cavities between filters began to be filled and biofilters absorbed high amount of ammonia from fish metabolic waste. Ammonia reduction rate showed the highest rate on week 4 . But despite of optimal function of integrated filters, this highest rate was due to the damage of aquaponic system. On week 4, ammonia that had previously accumulated in the system was flowed out and drained because of rain for 4 consecutive days.

\section{Growth of Catfish}

As a main component in aquaponic, growth of catfish is measured to gain information about fish farming effectivity. Main parameter to study on fish growth are its body weight and length, survival rate (SR) and feed conversion ratio (FCR). In general, Table 3 showed catfish were growing as shown by increasing value of body weight and length. Since research was conducted for 4 weeks and the measurement of growth parameters were done once per week, growth rate for catfish were obtained by comparing data from certain week to its previous week.

Catfish that were observed from week 1 to week 2 were very active, motile and has black skin colour. Comparison on body parameters between week 1 and week 2 showed data as follows : weight gain 13.47 g, length gain $1.26 \mathrm{~cm}, \mathrm{FCR}$ was 1.007 , and SR was 0.98 . The highest growth rate of catfish was observed on week 1 to week 2, where FCR and SR values were close to 1 (Table 3). This result might be supported by environmental parameters of water, such as temperature, $\mathrm{pH}$, and ammonia levels which are on the normal range as optimum fish farming condition.

From week 2 to week 3, catfish were physically observed having whitish skin color. Growth rate parameters data showed weight gain was 3.27 grams, length increase was $0.25 \mathrm{~cm}, \mathrm{FCR}$ was 1.095, and SR was 0.95 . The growth rate of catfish from week 2 to 3 were the lowest one. Increasing level of ammonia levels that surpassed threshold level of $0.8 \mathrm{ppm}$ (Anonim, 2005) could play role as major inhibition factor for growth rate of catfish (Hastuti and Subandiyono, 2011). Increased FCR value observed on week 2 to week 3 (if compared to week 1 to week 2) may contribute to the rate of catfish growth.

On week 3 to week 4 , catfish skin color were observed pale white and fish did not swim actively. Growth rate of catfish were shown as follows : weight gain was $13.39 \mathrm{~g}$, length gain $1.13 \mathrm{~cm}, \mathrm{FCR}$ was 1.096, and SR was 0.92. Catfish were assumed highly adaptive to environmental condition during week 3 to week 4 . It was shown by weight and length gained eventhough FCR and SR levels are less than what was observed in the previous week (Table 3). Catfish are able to live in extreme environments, such as low dissolved oxygen (DO) concentrations. In order to adapt on poor oxygen environment, catfish have an additional breathing apparatus that has a function to take oxygen directly from the air (Supardi, 2003). The decreased of survival rate on week 4 was due to the decrease of DO 
concentration in water pond (Table 1). Level of dissolved oxygen could effect ammonia concentrations in aquaculture environment (Haslam, 1995). Low DO levels will increase ammonia toxicity to animals, including catfish which has ability to adapt to extreme environments condition (Dauhan et al, 2014; Rini et al., 2018).

\section{Growth of Water Spinach}

Similar to the measurement of catfish growth, measurement of water spinach as plant component in aquaponics is based on its body or habitus development. Growth of water spinach was measured from its weight, length and number of leaves. Growth rate of water spinach were measured once a week on certain day and hour. The value of plant growth rate were obtained by comparing data from certain week to its previous week

As shown in Figure 3, physical appearance of water spinach from week 1 to week 2 showed fresh bright green leaves and their stems were growing straight up. Growth rate of plants that measured in this period all showed increase in average length $(10.3 \mathrm{~cm})$, average weight $(2.27 \mathrm{~g})$ and average number of leaves (3.72) as based on Table 4 . In this period, water spinach had a fast initial growth rate. During this initial period, plants were able to absorb nutrients for developing their organ size (Effendi et al., 2016). A fast initial growth rate as marked by increasing length of plant can also help reducing ammonia in aquaponics (Effendi et al., 2016). As shown in Table 2, ammonia levels on week 2 were lower than week 1 .

On the period of week 2 to week 3 , leaves of water spinach were yellowish and their stem began to bend. Growth rate in this periode consist of increase in average length $(7.86 \mathrm{~cm})$, increase in average weight $(1.82 \mathrm{~g})$ and increase in average number of leaves (1.82). On this period, the rate of plant growth was low due to the increased of water turbidity and ammonia concentration which prevented plants to absorb existing nutrients. The ability of plants to absorb nutrients will decrease as levels of turbidity and amonium concentration increase in the pond (Sugiharto, 1987 and Effendi, 2003).
Observation on week 3 to week 4 showed wilted and yelow color of water spinach leaves (Figure 3). All plant growth parameters were increasing, such as average length was $14.96 \mathrm{~cm}$, average weight was 0.27 grams, and average number of leaves was leaves 4.09 (as based on Table 4). Plants growth rate that was observed in this period showed highest rate that might be caused by the etiolation effect. Water spinach plants that tend to grow under the biofilter pipe will be exposed to less sunlight and causing fast growth but poor physical condition.

It is important to mention that occurrence of rain for 4 consecutive days on the terminal period of research caused physical damage to water spinach that was marked by broken stems (Figure 3). Rain drops also interfered water condition of the aquaponic system and might reduced its chemical composition, such as dissolved oxygen value and lead to abnormality of water spinach growth (Sikawa and Yakupitiyage, 2010; Sugiharto, 1987).

Taken together, integration of zeolit and charcoal as filter and water spinach as biofilter helped reducing ammonia level in water of aquaponic system and supported the growth of catfish during period of research.

\section{Conclusion}

Combination of zeolit and charcoal as materias for filters and water spinach as material for biofilter in an integrated filter system is potential to reduce ammonia waste in an aquaponics system. Reduction of ammonia level in water of aquaponics system could support the growth of fish as main component to be farmed in aquaponic.

\section{References}

Anonim (2005). Petunjuk Pembenihan Ikan Lele Sangkuriang Clarias sp. Balai Besar Pengembangan Budidaya Air Tawar (BBPBAT). Sukabumi

Atima, W. (2015). BOD dan COD Sebagai Parameter Pencemaran Air dan Baku Mutu Air Limbah. Biosel: Biology Science and Education, 4(1), 83-93.

Augusta, T. S. (2016). Dinamika Perubahan Kualitas Air Terhadap Pertumbuhan 
Ikan Lele Dumbo (Clarias gariepinus) yang Dipelihara di Kolam Tanah. Jurnal Ilmu Hewani Tropika, 5(1).

Boyd, C. E. \& A, Nill. (1982). Water Quality Management for Pound Fish. Elsevier Sci. Pub. Co., Amsterdam.

Dauhan, R. E. S., Efendi, E., \& Suparmo (2014). Efektifitas Sistem Akuaponik Dalam Mereduksi Konsentrasi Amonia pada Sistem Budidaya Ikan. E-Jurnal Rekayasa dan Teknologi Budidaya Perairan, Vol. III.

Dewantoro, G. W. (2001). Fekunditas dan produksi larva pada ikan cupang (Betta splendens Regan) yang berbeda umur dan pakan alaminya. Fakultas Biologi, Universitas Nasional Jakarta. Jurnal Iktiologi Indonesia, 1(2); 49 - 52

Djokosetiyanto, D.,Sunarma, A., \&Widanarni. (2006). Perubahan Ammonia $\left(\mathrm{NH}_{3}-\mathrm{N}\right)$, Nitrit $\left(\mathrm{NO}_{2}-\mathrm{N}\right)$ dan Nitrat $\left(\mathrm{NO}_{3}-\mathrm{N}\right)$ pada Media Pemeliharaan Ikan Nila Merah (Oreochromis sp.) di dalam Sistem Resirkulasi. Jurnal Akuakultur Indonesia, $\mathrm{V}(1):$ 13-20.

Effendi, H. (1979). Biologi Perikanan. Yayasan Nusantara. Bogor

Effendi, H. (2003). Telaah Kualitas Air Bagi Pengelolaan Sumber Daya dan Lingkungan. Kanisius: Yogyakarta.

Effendi, I. Bugri, N. J., \& Widanarni. (2006). Pengaruh padat penebaran terhadap kelangsungan hidup dan pertumbuhan benih ikan gurami Osphronemus gouramy. ukuran $2 \mathrm{~cm}$. Jurnal Akuakultur Indonesia, 5(2); 127-135.

Effendi, H., Amarullah, U.B., Darmawangsa, G.M. \& Karo karo, R. E.(2016). Fitoremediasi Limbah Budidaya Ikan Lele (Clarias sp.) Dengan Kangkung (Ipomoea aquatica) Dan Pakcoy (Brassiica rapa chinensis) Dalam Sistem Resirkulasi. Jurnal Ecolab, 9(2): 47104.

Graber, A \& Junge, R. (2009). Apuaponic System : Nutrient recycling from fish wastewater by vegetable production. Elsevier, 147-156.

Haslam, S. M. (1995). River Pollution and Ecological Perspective. John Wiley and Sons, Chichester, UK.
Hastuti, S \& Subandiyono. (2011). Performa Hematologis Ikan Lele Dumbo (Clarias gariepinus) dan Kualitas Air Media pada Sistem Budidaya dengan Penerapan Kolam Biofilter. Jurnal Saintek Perikanan 6:1-5.

Hu Z., Lee J. W., Chandran K., Kim S., Brotto A. C., \& Khanal S. K. (2015). Effect of plant species on nitrogen recovery in aquaponics. Bioresource Technology 188; 92-98.

Lund, J. (2014). Aquaculture Effluents as Fertilizer in Hydroponic Cultivation: A Case Study Comparing Nutritional and Microbiological Properties. Swedish University of agricultural Science.

Machdar, I. (2018). Pengantar Pengendalian Pencemaran: Pencemaran Air, Pencemaran Udara, dan Kebisingan. Yogyakarta, Indonesia: Deepublish.

Nisrinah, S \& T. Elfitasari. (2013). Pengaruh Penggunaan Bromelin Terhadap Tingkat Pemanfaatan Protein Pakan dan Pertumbuhan Lele Dumbo (Clarias gariepinus). Journal of Aquaculture Management and Technology, 2(2); 57-63.

Norjanna, F., Efendi, E., \& Hasani, Q. (2015). Reduksi Amonia Pada Sistem Resirkulasi Dengan Penggunaan Filter yang Berbeda. E-Jurnal Rekayasa Dan Teknologi Budidaya Perairan, Vol. IV(1).

Nugroho, R. A., Pambudi, L. T., Chilmawati, D., \& Haditomo, A. H. C. (2012). Aplikasi Teknologi Aquaponic Pada Budidaya Ikan Air Tawar Untuk Optimalisasi Kapasitas Produksi. Jurnal Saintek Perikanan, 8(1);46-51.

Putra, Iskandar \& N.A Pamukas. (2011). Pemeliharaan Ikan Selais (Ompok sp.) dengan Resirkulasi, Sistem Aquaponik. Jurnal Perikanan dan Kelautan, XVI (1): 125-131.

Rini, D. S., Hasan, H., \& Prasetio, E. (2018). Sitem Akuaponik Dengan Jenis Tumbuhan yang Berbeda Terhadap Pertumbuhan Benih Ikan Tengadak (Barbonymus scwanenfeldii). Jurnal Ruaya, 6.

Salle, A.J. (1961). Fundamental Principles of Bacteriology. Fifth edition. Mc Graw hill book company, Inc. New York,812 pp 
Setijaningsih, L. (2009). Peningkatan Produktivitas Kolam Melalui Perbedaan Jarak Tanam Tanaman Akuaponik Pada Pemeliharaan Ikan Mas (Cyprinus carpio). Laporan Hasil Riset Perikanan Budidaya Air Tawar Bogor Tahun 2009.

Sikawa, D.C. \& Yakupiyiyage, A. (2010). The hydroponic production of lettuce (Lactuca sativa l) by using hybrid catfish (Clarias macrocephalus x C.gariephinus) pond water: potentials and constraints. Agriculture Water Management, 97:13171325

Sugiharto. (1987). Dasar-dasar Pengolahan Air Limbah. Jakarta (ID): UI Press

Supardi, L. (2003). Kiat Sukses Budidaya Lele di Lahan Sempit. Agromedia Pustaka. Jakarta

Telaumbanua, M. Purwantana, B. Sutiarso, L., \& Fallah, M. A. (2016). Studi Pola Pertumbuhan Tanaman Sawi (Brassica rapa var. parachinensis L.) Hidroponik Di Dalam Greenhouse Terkontrol. Jurnal AGRITECH, 36 (1); 104 -110

Wahyuningsih, S., Effendi, H., \& Wardiatno, Y.(2015). Nitrogen removal of aquaculture wastewater in aquaponic recirculation system. AACL Bioflux, VIII(4).

Widayat, A. R \& Rachimoellah, M. (2010). Pengaruh Waktu Dealuminasi Dan Jenis Sumber Zeolit Alam Terhadap Kinerja H-Zeolit Untuk Proses Dehidrasi Etanol. Reaktor, 13(1), 52.

Widyastuti, Y. R. (2008). Peningkatan Produksi Air Tawar melalui Budidaya Ikan Sistem Akuaponik. Prosiding Seminar Nasional Limnologi IV LIPI. Bogor : $62-73$

Yuwono, Sukardi, E. P., \& Sulistiyo, I. (2005) .Konsumsi dan Efesiensi Pakan Pada Ikan Kerapu Bebek (Cromileotes altivelis) yang Dipuasakan Secara Periodik. Berkala Penelitian Hayati. 